\title{
PLATELET COUNT/SPLEEN DIAMETER RATIO: analysis of its capacity as a predictor of the existence of esophageal varices
}

\author{
Ângelo Zambam de MATTOS $^{1,2}$, Angelo Alves de MATTOS $^{1,2}$, Fernanda Farias VIANNA ${ }^{1,2}$, \\ Maiara Isabel MUSSKOPF ${ }^{1,2}$, Júlio Carlos PEREIRA-LIMA ${ }^{1,2}$ and Antônio Carlos MACIEL ${ }^{2}$
}

\begin{abstract}
Context - Upper gastrointestinal bleeding associated to esophageal varices is the most dramatic complication of cirrhosis. It is recommended screening every cirrhotic for esophageal varices with endoscopy. Objectives - To evaluate the capacity of the platelet count/spleen diameter ratio in non-invasively predicting esophageal varices in a population of cirrhotics originated in an independent center from the one in which it was developed. Methods - The study included patients from the ambulatory care clinic of cirrhosis of a Brazilian hospital and studied platelet count, spleen diameter and presence of esophageal varices, as well as Child and MELD scores. It used a cutoff value of 909 for the platelet count/spleen diameter ratio, as previously published. A sample of 139 patients was needed to grant results a 95\% confidence level. Results - The study included 164 cirrhotics, $56.7 \%$ male, with a mean age of $56.6 \pm 11.6$ years. In the univariate analysis, platelet count, spleen diameter, presence of ascites, Child and MELD scores and the platelet count/spleen diameter ratio were related to esophageal varices $(P<0.05)$. The platelet count/spleen diameter ratio had sensitivity of $77.5 \%(95 \% \mathrm{CI}=0.700-0.850)$, specificity of $45.5 \%(95 \% \mathrm{CI}=0.307-0.602)$, positive predictive value of $79.5 \%(95 \%$ $\mathrm{CI}=0.722-0.868)$, negative predictive value of $42.6 \%(95 \% \mathrm{CI}=0.284-0.567)$ and accuracy of $68.9 \%(95 \% \mathrm{CI}=0.618-0.760)$. In the multivariate analysis, platelet count was the only variable which related to esophageal varices $(P<0.05)$. Conclusion - Platelet count/ spleen diameter ratio is not adequate to predict esophageal varices in cirrhotics.
\end{abstract}

HEADINGS - Liver cirrhosis. Esophageal and gastric varices. Platelet count. Spleen.

\section{INTRODUCTION}

Upper gastrointestinal bleeding (UGB) caused by rupture of gastric and, mainly, esophageal varices (EV) is the most dramatic complication of cirrhosis. The prevalence of $\mathrm{EV}$ in cirrhotic patients varies between $60 \%$ and $80 \%{ }^{(11)}$. Bleeding caused by its rupture implies a mortality rate of $17 \%$ to $57 \%$ to this kind of patients ${ }^{(11)}$, being one of the criteria used to indicate liver transplantation. Bleeding recurrence may reach the level of $70 \%$ in 1 year $^{(15)}$.

Because of the impact of UGB caused by rupture of $\mathrm{EV}$ in the prognosis of cirrhotic patients, the American Association for the Study of Liver Diseases (AASLD) ${ }^{(9)}$ and the Baveno Consensus ${ }^{(5,6)}$ have determined that every patient diagnosed with cirrhosis should be investigated for EV. Endoscopy will be repeatedly performed during these patients' lives ${ }^{(9)}$.

Along with secondary prophylaxis against UGB by rupture of $\mathrm{EV}$, primary prophylaxis is advocated each time more vigorously, mainly for medium and large varices (or for those with red marks) ${ }^{(8)}$, but also for small varices in some instances as it is proposed by the AASLD ${ }^{(9)}$. The indication of primary prophylaxis reinforces the importance screening cirrhotic patients for EV.

Non-invasive methods to screen cirrhotic patients are being researched in order to spare them from the discomfort and risks of endoscopy and to cut costs from the health systems. Some of them are platelet count, splenomegaly, portal vein diameter, Child-Pugh classification, prothrombin activity, telangectasias, ascites, transient elastography and a model including spider angiomas, ALT and albumin ${ }^{(2,}$ $4,5,7,20)$. Some of these variables have deserved more attention, mainly those related to portal hypertension, as thrombocytopenia and splenomegaly ${ }^{(11)}$. The measurement of platelets and spleen size are part of the routine work up of cirrhotic patients and, therefore, would not implicate increase in costs. Giannini et al. ${ }^{(10,11)}$ have proposed the use of an index between the number of platelets and the 
spleen diameter in millimeters ${ }^{(3,8,10,11,12,16,19,21)}$. A cut off value of 909 was described to have a negative predictive value of $100 \%$ and a positive predictive value of $96 \%$ for the existence of $\mathrm{EV}^{(11)}$.

This study evaluates the capacity of this index in predicting the existence of EV in a developing country, which has not been done yet. Even more importantly, it evaluates its performance in a population originated in a totally independent center from the one in which it was developed.

\section{METHODS}

Patients from the ambulatory care clinic of cirrhosis of Santa Casa Hospital of Porto Alegre, RS, Brazil, were revised. They should have platelet count, ultrassonography and endoscopy 6 months of each other at most. Flux cytometry was used to determine platelet count (ADVIA 2120, Siemens Medical Solutions Diagnostics, Dublin, Ireland).

EV were graded in size and form according to Beppu et al. ${ }^{(1)}$. This study took place between December 2006, when the protocol was established involving the Gastroenterology and the Radiology Units of the Hospital, and September 2007.

It was used the cut off value of 909 proposed by Giannini et al. ${ }^{(11)}$. Patients with a platelet count/spleen diameter ratio greater than this cut off were supposed not to have EV. Data were calculated in order to verify sensitivity, specificity, negative and positive predictive values of the index, with a confidence interval of $95 \%$ and with a $P$ value of $5 \%$. The Student $t$ test was used for the continuous variables and the Chi-Square test for the categorical ones. After the univariate analysis, the significant variables were submitted to a logistic regression. Epi InfoTM 3.4.1 was used for the statistical analysis.

It was calculated that at least 139 patients were needed to produce results with a $95 \%$ level of confidence and a $10 \%$ length for the confidence intervals ${ }^{(13)}$, taking into account a sensibility of more than $90 \%$, as proposed by Giannini et al. ${ }^{(11)}$. This study was approved by the Ethics Committee of Santa Casa Hospital, Porto Alegre, RS.

\section{RESULTS}

One hundred and sixty four patients integrated the study. There were 93 men $(56.7 \%)$. The mean age of the studied population was $56.6 \pm 11.6$ years. Cirrhosis was caused by viral hepatitis (hepatitis B virus-HBV or hepatitis $\mathrm{C}$ virus$\mathrm{HCV}$ ) in 72 patients $(43.9 \%)$, being only 4 of them infected with HBV. Alcohol intake was its cause in 48 cases $(29.3 \%)$. Viral hepatitis in association with alcohol was implicated in 17 cases $(10.4 \%)$. Other causes of liver disease accounted for 27 cases $(16.5 \%)$.

Eighty seven patients (57.6\%) were Child-Pugh class A, 57 $(37.7 \%)$ were Child B, and 7 (4.6\%) were Child C. The mean MELD score ${ }^{(14)}$ in the studied population was 9.2.

Mean platelet count was 96,762. Mean spleen diameter was $146.2 \mathrm{~mm}$. Mean platelet count/spleen diameter ratio was 744.4 .
There were 120 patients with EV on endoscopy (73.2\%), $52(43.3 \%)$ of them classified as grade I/III, $49(40.8 \%)$ as grade II/III and $15(12.5 \%)$ as grade III/III. Four patients did not have their varices classified (Table 1).

\begin{tabular}{ll} 
TABLE 1. - Characteristics of the sample \\
\hline Patients & $164(100 \%)$ \\
Male & $93(56.7 \%)$ \\
Mean age (years) & 56.6 \\
Cause of cirrhosis & \\
Viral hepatitis & $72(43.9 \%)$ \\
Alcohol & $48(29.3 \%)$ \\
Viral hepatitis + Alcohol & $17(10.4 \%)$ \\
Other & $27(16.5 \%)$ \\
Mean platelet count & 96,762 \\
Spleen diameter (mm) & 146.2 \\
Mean platelet count/spleen diameter ratio & 744.4 \\
Child-Pugh classification & \\
A & $87(57.6 \%)$ \\
B & $57(37.7 \%)$ \\
C & $7(4.6 \%)$ \\
Mean MELD & 9.2 \\
Esophageal varices on endoscopy* & 120 \\
Grade I/III & $52(43.3 \%)$ \\
Grade II/III & $49(40.8 \%)$ \\
Grade III/III & $15(12.5 \%)$ \\
\hline
\end{tabular}

*Four parients did not have their varices classified.

Ninety three patients $(79.5 \%)$ with platelet count/ spleen diameter ratio $\leq 909$ had $\mathrm{EV}$, while $24(20.5 \%)$ did not have EV on endoscopy; 27 cases $(57.4 \%)$ with platelet count/spleen diameter ratio $>909$ had EV and $20(42.6 \%)$ did not; platelet count/spleen diameter ratio was different between the groups for a $P=0.004$. It had a sensitivity to predict $\mathrm{EV}$ of $77.5 \%(95 \% \mathrm{CI}=0.700-0.850)$, a specificity of $45.5 \%(95 \% \mathrm{CI}=0.307-0.602)$, a positive predictive value of $79.5 \%(95 \% \mathrm{CI}=0.722-0.868)$, a negative predictive value of $42.6 \%(95 \% \mathrm{CI}=0.284-0.567)$ and an accuracy of $68.9 \%(95 \% \mathrm{CI}=0.618-0.760)$.

The univariate analysis was also performed with the other variables in question. Mean platelet count in the group without EV was 124,682 , while it was 86,525 in the group who had EV $(P=0.0001)$. Mean spleen diameter was $136.16 \mathrm{~mm}$ and $149.93 \mathrm{~mm}$ respectively $(P=0.0137)$. Fourteen patients had ascites and all of them had EV $(P$ $=0.01$ ). Of the cases classified as Child A, 66\% had EV, while $84.4 \%$ of those classified as Child B or C had EV on endoscopy $(P=0.0098)$. Mean MELD score was 10.25 for patients without EV and 12.01 for the ones with $\mathrm{EV}(P=$ 0.02 ). The sample was not big enough to verify the association of the different causes of cirrhosis and the presence of $\mathrm{EV}$; this was because the sample size had been calculated to the analysis of platelet count/spleen diameter ratio, which is a dichotomic variable.

When the variables were submitted to the multivariate analysis, only platelet count remained significantly different between patients with and without EV $(P=0.0004)$. 


\section{DISCUSSION}

It is of great interest selecting cirrhotic patients at a major risk of having EV in a non-invasive manner in order to submit them to endoscopy. This is an invasive and expensive procedure, which could be unnecessary in a group of the patients diagnosed as cirrhotic. For the non-invasive test to be useful, it would be mandatory that it would have a great negative predictive value, once misdiagnosing cirrhotic patients as not having EV is a major risk.

In the cirrhotic patients, platelets are reduced by different causes: portal hypertension (through hypersplenism), antibodymediated platelet destruction (mainly in viral hepatitis), decreased thrombopoietin production and myelotoxic effects of alcohol and hepatitis virus. The rational of the platelet count/spleen diameter ratio would be to correct thrombocytopenia for other causes which not portal hypertension, once splenomegaly in cirrhosis is in fact caused by portal hypertension ${ }^{(17)}$.

Our study found that $73.2 \%$ of the cirrhotic patients had EV diagnosed by endoscopy. This result is similar to the range of $24 \%$ to $80 \%$ showed in literature ${ }^{(7)}$ and reminds us that a significant part of cirrhotic patients are unnecessarily submitted to this procedure. Knowing which are these patients by a non-invasive test would prevent the risks and the discomfort of the procedure, as well as reduce its burden to the health system. The platelet count/spleen diameter ratio was considered the best non-invasive predictor of EV developed ${ }^{(7)}$. This method uses two easily obtained parameters, which are part of the routine of the assistance to a cirrhotic patient and, thus, would not increase costs. Besides, spleen diameter and platelet count are not variables predisposed to significant measure errors; in our laboratory, for instance, the biological variation coefficient for platelet count is very low, respecting the recommended limits.

Even though we found platelet count/spleen diameter ratio to be associated with the presence of $\mathrm{EV}$ at the univariate analysis, it did not show the same negative or positive predictive values, nor the sensitivity, specificity or accuracy published before $^{(10,11,12,21)}$. Our results do not support the use of this test, once the risk of missing people with EV would be great, and its consequences could be very deleterious. Our results are of great importance, once they are the first published independently of the center which proposed the test. They show that the results of the platelet count/spleen diameter ratio probably cannot be generalized to other populations and that the data published in the multicenter trial by Giannini et al. ${ }^{(12)}$ was probably biased by the enrollment of an important group of patients of the center in which the index had been produced. This hypothesis was already proposed by De Franchis $^{(6)}$ in an editorial.

Besides this, in the multivariate analysis, platelet count/ spleen diameter ratio did not even correlate with the existence of EV. This could imply that the association between both variables in the univariate analysis could have been influenced by the association between a low platelet count and the presence of $\mathrm{EV}$, since this was the only variable related to $\mathrm{EV}$ after the multivariate analysis. This possibility had also already been proposed in literature ${ }^{(18)}$. In a recent paper by the Barcelona group, made in order to evaluate non-invasive prediction of clinically significant portal hypertension and EV, the platelet count/spleen diameter ratio was not associated to EV either; although it is necessary to state that the research was not planed to make this analysis ${ }^{(2)}$.

In the univariate analysis, besides platelet count and platelet count/spleen diameter ratio, mean spleen diameter, presence of ascitis, Child-Pugh classification and MELD score were related to the presence of EV. Some of these variables and others not studied by us have already shown to be associated with the presence of $\mathrm{EV}^{(2,4,5,7,20)}$. In the multivariate analysis of our research, though, the only variable significantly associated to EV was the platelet count.

In conclusion, we do not consider platelet count/spleen diameter ratio to be an adequate index to predict the existence of $\mathrm{EV}$ in cirrhotic patients. To the moment, we still think cirrhotic patients must be submitted to a screening endoscopy in order to verify for the presence of $\mathrm{EV}$ at the moment of their diagnosis. It is important that other non-invasive tests be developed in order to reduce the number of unnecessary endoscopies.

Mattos AZ, Mattos AA, Vianna FF, Musskopf MI, Pereira-Lima JC, Maciel AC. Índice contagem de plaquetas/diâmetro do baço: análise de sua capacidade como preditor da existência de varizes esofágicas. Arq Gastroenterol. 2010;47(3):275-8.

RESUMO - Contexto - Hemorragia digestiva por varizes esofágicas é a complicação mais dramática da cirrose. É recomendada triagem de varizes esofágicas em todo o cirrótico. Objetivo - Avaliar o índice de contagem de plaquetas/diâmetro do baço como predição de varizes esofágicas em uma população distinta daquela em que ele foi desenvolvido. Métodos - O estudo incluiu pacientes do ambulatório de cirrose de um hospital brasileiro quanto ao número de plaquetas, diâmetro ecográfico do baço, presença de varizes esofágicas, Child e MELD. O ponto de corte do índice foi de 909. Amostra de 139 pacientes foi estimada para conferir nível de confiança de 95\%. Resultados - Incluíram-se 164 cirróticos, 56,7\% homens e com média de idade de 56,6 anos. Na análise univariada, número de plaquetas, diâmetro do baço, ascite, Child, MELD e o índice de contagem de plaquetas/ diâmetro do baço relacionaram-se às varizes esofágicas $(P<0,05)$. Na multivariada, só a contagem de plaquetas associou-se a elas $(P<0,05)$. $O$ índice de contagem de plaquetas/diâmetro do baço apresentou sensibilidade de 77,5\% (IC 95\% = 0,700-0,850), especificidade de 45,5\% (IC 95\% = 0,307-0,602), valor preditivo positivo de 79,5\% (IC 95\% = 0,722-0,868), valor preditivo negativo de 42,6\% (IC95\% = 0,284-0,567) e precisão de 68,9\% (IC 95\% = 0,618-0,760). Conclusão - O índice de contagem de plaquetas/diâmetro do baço não é adequado para a triagem de varizes esofágicas em cirróticos.

DESCRITORES - Cirrose hepática. Varizes esofágicas e gástricas. Contagem de plaquetas. Baço. 


\section{REFERENCES}

1. Beppu K, Inokuchi K, Koyanagi N, Nakayama S, Sakata H, Kitano S, Kobayashi M. Prediction of variceal hemorrhage by esophageal endoscopy. Gastrointest Endosc. 1981;27:213-8

2. Berzigotti A, Gilabert R, Abraldes JG, Nicolau C, Bru C, Bosch J, García-Pagan JC. Noninvasive prediction of clinically significant portal hypertension and esophageal varices in patients with compensated liver cirrhosis. Am J Gastroenterol. 2008;103:1159-67.

3. Bosch J, Garcia-Pagán JC, Berzigotti A, Abraldes JG. Measurement of portal pressure and its role in the management of chronic liver disease. Semin Liver Dis. 2006;26:348-62.

4. Burton JR, Liangpunsakul S, Lapidus J, Giannini E, Chalasani N, Zaman A. Validation of a multivariate model predicting presence and size of varices. J Clin Gastroenterol. 2007;41:609-15.

5. de Franchis R. Evolving consensus in portal hypertension report of the Baveno IV consensus workshop on methodology of diagnosis and therapy in portal hypertension. J Hepatol. 2005;43:167-76.

6. de Franchis R. Noninvasive diagnosis of esophageal varices: is it feasible? Am J Gastroenterol. 2006;101:2520-2.

7. de Franchis R, Dell'Era A. Diagnosis and therapy of esophageal vascular disorders. Curr Opin Gastroenterol. 2007;23:422-7.

8. Garcia-Tsao G. Portal hypertension. Curr Opin Gastroenterol. 2006;22:254-62.

9. Garcia-Tsao G, Sanyal AJ, Grace ND, Carey W; Practice Guidelines Committe of the American Association for the Study of Liver Diseases; Practice Parameters Committee of the American College of Gastroenterology. Prevention and management of gastroesophageal varices and variceal hemorrhage in cirrhosis. Hepatology. 2007;46:922-38.

10. Giannini E, Botta F, Borro P, Risso D, Romagnoli P, Fasoli A, Mele MR, Testa E, Mansi C, Savarino V, Testa R. Platelet count/spleen diameter ratio: proposal and validation of a non-invasive parameter to predict the presence of oesophageal varices in patients with liver cirrhosis. Gut. 2003;52:1200-5.

11. Giannini EG, Botta F, Borro P, Dulbecco P, Testa E, Mansi C, Savarino V, Testa R Application of the platelet count/spleen diameter ratio to rule out the presence of oesophageal varices in patients with cirrhosis: a validation study based on follow-up. Dig Liver Dis. 2005;37:779-85.
12. Giannini EG, Zaman A, Kreil A, Floreani A, Dulbecco P, Testa E, Sohaey R, Verhey P, Peck-Radosavljevic M, Mansi C, Savarino V, Testa R. Platelet count/spleen diameter ratio for the noninvasive diagnosis of esophageal varices: results of a multicenter, prospective, validation study. Am J Gastroenterol. 2006;101:2511-9.

13. Hulley SB, Cummings SR, editors. Designing clinical research: an epidemiological approach. Baltimore: Williams \& Wilkins; 1988. p.215.

14. Kamath PS, Wiesner RH, Malinchoc M, Kremers W, Therneau TR, Kosberg CL, D'Amico G, Dickson ER, Kim WR. A model to predict survival in patients with end-stage liver disease. Hepatology. 2001;33:464-70.

15. Mattos AA. Hipertensão portal - prevenção primária da hemorragia digestive alta. In: Parada AA, Capellanes CA, Vargas C, Venco FE, Mansur GR, Paes IB, Andreoli JC, Ardengh JC, Galvão LPR, Albuquerque W, editores. Endoscopia gastrointestinal terapêutica. São Paulo: Tecmedd; 2006. p.826-32.

16. Nanda M, Bhasin DK, Sinha SK, Nagi B. Non-endoscopic prediction of small and large esophageal varices in patients with portal hypertension [abstract]. J Gastroenterol Hepatol. 2004;19(Suppl):A738.

17. Testa R, Testa E, Giannini E, Borro P, Milazzo S, Isola L, Ceppa P, Lantier $\mathrm{PB}$, Risso D. Noninvasive ratio indexes to evaluate fibrosis staging in chronic hepatitis C: role of platelet count/spleen diameter ratio index. J Intern Med. 2006:260:142-50.

18. Thabut D, Ratziu V, Trabut JB, Poynard T. Prediction of oesophageal varices with platelet count/spleen diameter ratio or platelets alone. Gut. 2004;53:913-5.

19. Thayumanavan DRL, Jegannathan DRASA, Cherian DRJ, Ayyappan DR. Platelet count to spleen diameter ratio as a prediction of oesophageal varices [abstract]. J Gastroenterol Hepatol. 2004;19(Suppl):A727.

20. Thomopoulos KC, Labropoulou-Karatza C, Mimidis KP, Katsakoulis EC, Iconomou G, Nikolopoulou VN. Non-invasive predictors of the presence of large oesophageal varices in patients with cirrhosis. Dig Liver Dis. 2003;35:473-8.

21. Zimbwa TA, Bhanshard C, Subramaniam A. Platelet count/spleen diameter ratio as a predictor of esophageal varices in alcoholic cirrhosis. Gut. 2004;53:1055.

Received 11/11/2009.

Accepted 2/2/2010 